\title{
Modeling water quality index to assess shallow groundwater quality for sustainable utilization in Southern India
}

\author{
Anbazhagan S *, Jothibasu A \\ Centre for Geoinformatics and Planetary Studies, Department of Geology, Periyar University, Salem 636011 , India \\ *Corresponding author E-mail: anbu02@gmail.com
}

\begin{abstract}
In sustainable groundwater study, it is necessary to assess the quality of groundwater in terms of drinking and irrigation purposes. The present study attempt to assess the groundwater quality through Drinking Water Quality Index (DWQI) and Irrigation Water Quality Index (IWQI) in hard rock aquifer system and sustainable water use in Uppar Odai sub-basin, Southern India. The quality of ground water in major part of the study area is generally poor. In order to understand the shallow groundwater quality, the water samples were collected from 24 dug wells. The primary physical and chemical parameters like potential Hydrogen (pH), Total Dissolved Solids (TDS), Total Hardness $(\mathrm{TH})$, calcium $(\mathrm{Ca})$, magnesium $(\mathrm{Mg})$, sodium $(\mathrm{Na})$, potassium $(\mathrm{K})$, bicarbonate $\left(\mathrm{HCO}_{3}\right)$, carbonate $\left(\mathrm{CO}_{3}\right)$, cloride $(\mathrm{Cl})$, sulphate $\left(\mathrm{SO}_{4}\right)$, nitrate $\left(\mathrm{NO}_{3}\right)$ and fluoride $(\mathrm{F})$ were analyzed for DWQI. The secondary parameters of irrigation groundwater quality indices such as Sodium Adsorption Ratio (SAR), Sodium Soluble Percentage (SSP), Residual Sodium Carbonate (RSC), Permeability Index (PI), Corrosively Ratio (CR), Magnesium Adsorption Ratio (MAR) and Kellies Ratio (KR) were also derived from the primary parameter for IWQI. The DWQI and IWQI were classified into excellent to unfit condition of groundwater quality based on their Water Quality Index (WQI). The spatial distribution of DWQI (25\%) and IWQI (58+26\%) indicate that slightly unsustainable to sustainable state of groundwater quality. Due to this quality deterioration of shallow aquifer, an immediate attention required for sustainable development.
\end{abstract}

Keywords: Groundwater Quality, GIS, Water Quality Indices, Shallow Aquifer, Sustainable Development.

\section{Introduction}

In arid and semi-arid areas, groundwater is considered as the major source of usable water, so that quality of water is the main key factor in management of groundwater in a sustainable manner. In the past few decades, reports of ground water contamination have increased public concern about ground water quality (Yanggen and Born, 1990). Subsurface leaching of contaminants from landfills as well as seepage from canals, rivers and drains cause severe degradation of the ground water quality. Adsorption and dispersion processes in the soil zone, degrees of evaporation, recharge and lateral inter-mixing of ground water determine the level of contaminations in ground water. Exploitation of vital ground water source leads to lowering of the ground water table and water quality deterioration. The groundwater pollution in different countries was mainly due to lack of proper waste management (Nkolika and Onianwa, 2011).

Groundwater quality assessment through various graphical methods and interpreted different indices were attempted by many workers in the recent past (Elango et al. 2003; Singh et al. 2006; Subbarao 2006; Pophare and Dewalkar 2007; Rashid and Izrar 2007). Geochemical processes are responsible for the seasonal and spatial variations in groundwater quality (Matthess 1982). Ben Hammou (1995) integrated groundwater geochemistry and cartography using GIS techniques. GIS is a powerful tool to assess the groundwater quality, determining the availability of water, preventing flooding, understanding the natural environment and managing water resources on a local as well as regional scale
(Collet, 1996). Vinten and Dunn (2001) studied the effects of land use on temporal changes in well water quality. Anbazhagan and Archana Nair (2004) have utilized such GIS technique to highlight the ground water quality in Panvel basin, Maharastra. The problems of groundwater quality are more acute in areas that are densely populated thickly industrialized and have shallow groundwater tube wells (Shivran et al. 2006). Pandian and Sankar (2007) have observed that host rocks are the main source of dissolved solids in the groundwater of the Viappar River basin, Tamil Nadu.

Groundwater $(\mathrm{GW})$ in shallow aquifer is a major source for drinking and irrigation water. Contamination of groundwater resulting from inherent composition of aquifer material or from human activities reduces the supply of safe drinking water, posing a threat to public health and thereby a great challenge to water managers and policy makers. Water quality index (WQI) is defined as a technique of rating that provides the composite influence of individual water quality parameter on the overall quality of water. Assessment of groundwater quality data based on different irrigation indices in different areas (Quddus and Zaman, 1996; Talukder et al., 1998; Shahidullah et al., 2000; Sarkar and Hassan, 2006; Raihan and Alam, 2008). The standards for drinking purpose have been considered for calculation of WQI (Ramakrishnaiah et al., 2009). In this method the weightage for various water quality parameters is assumed to be inversely proportional to the recommended standards for the corresponding parameters (Khwakaram et al., 2012). Rajankar et al. (2009) calculated WQI for different groundwater sources, viz., dug wells, bore wells, and tube wells at Khaperkheda Region, Maharashtra. The objective of present study 
is to assess the shallow groundwater quality of Uppar Odai subbasin for drinking and irrigation purposes through different groundwater quality indices and generate WQI maps.

\section{Study area}

The study area Uppar Odai sub-basin is in part of Amaravati river basin and covered 1280 sq. $\mathrm{km}$ area, fall in between longitudes $77^{\circ} 6^{\prime} 36^{\prime \prime} \mathrm{E}$ to $77^{\circ} 32^{\prime} 24^{\prime \prime} \mathrm{E}$ and latitudes $10^{\circ} 26^{\prime} 40^{\prime \prime} \mathrm{N}$ to $10^{\circ} 55^{\prime} 48^{\prime \prime} \mathrm{N}$ (Fig.1). The average annual rainfall of the sub-basin is $625 \mathrm{~mm}$, which is much lower than state average rainfall $(970 \mathrm{~mm})$. The agriculture, current fallow land and land under other uses are 39\%, $21 \%$ and $31 \%$ respectively in total geographical area of the Uppar Odai sub-basin. The study area comprises of crystalline rocks of Precambrian age. The area mostly depends on ground water resources for the agricultural development. In this region, ground water occurs in almost all geological formations at a depth of $>10$ $\mathrm{m} \mathrm{bgl}$. This is due to extensive mining of ground water for agricultural practices. Hence, with continuous demand for water supply, inadequate surface water and decline of ground water table. The existing reports stated that the Uppar Odai sub-basin is highly polluted due to high concentration of dissolved substances (Palanysami, 1998, CGWB, 2012).

\section{Geology and hydrogeology}

The study area is underlined by a wide range of high grade metamorphic rocks of the Peninsular Gneissic Complex. The rocks are extensively weathered and overlain by recent valley fills and alluvium at places. The southernmost part of the Indian Peninsula is a complex zone particularly characterized by rocks of granulite facies. The granulite terrain is not solely composed of rocks of granulite facies, but also Amphibolite facies, gneisses and 'supracrustal' rocks are abundant, and some of these lower grade rocks may represent areas of retrogression from granulite. The study area is solely composed of hornblende biotite gneiss, charnockite, pink migmatite, ultrabasic rocks, calc-silicate rocks, granite and pyroxene granulite (Viswanathan 1969, Narayanaswamy 1975). The water table decline in the sub-basin is ranges from $5 \mathrm{~m}$ to $16 \mathrm{~m}$ bgl. At few locations, the water table decline has noticed after a period of 20 years gap.

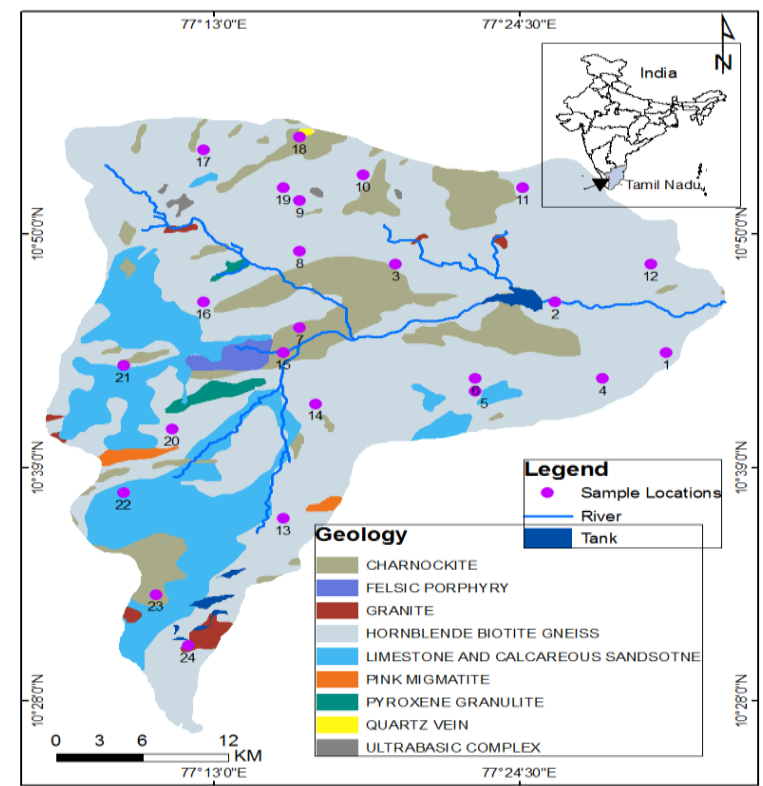

Fig. 1: Location Map of the Study Area Show Geology and Groundwater Sample Locations

\section{Materials and method}

Survey of India topographic maps, geology map published by GSI (1998), groundwater quality data and World Health Organization (WHO) water quality standards were utilized in the present study. The ArcGIS 9.3 software is used for data generation and spatial integration. The topographic maps were utilized for extraction of basin information such as roads and drainages. Sampling was carried out during post monsoon season for the year 2011. A total of twenty four water samples were collected from the selected locations throughout the study area (Fig.1). Inverse distance weighted (IDW) raster interpolation technique of spatial analyst module in ArcGIS software has been used for the present study to delineate the locational distribution of various water samples. The different locations of the sampling stations were imported into GIS software through point layer. Each sample point was assigned by a unique code and stored in the point attribute table. The data base file contains values of all chemical parameters in separate columns along with a sample code for each sampling station. The geodatabase was used to generate the spatial distribution maps of selected water quality parameters namely $\mathrm{pH}$, TDS, $\mathrm{TH}, \mathrm{Ca}, \mathrm{Mg}$, $\mathrm{Na}, \mathrm{K}, \mathrm{HCO}_{3}, \mathrm{CO}_{3} \mathrm{Cl}, \mathrm{SO}_{4}, \mathrm{NO}_{3}$ and $\mathrm{F}$ were analyzed for DWQI. The statistical analysis of various quality parameters are given in Table 1 . The secondary parameters of irrigation groundwater quality indices such as Sodium Adsorption Ratio (SAR), Sodium Soluble Percentage (SSP), Residual Sodium Carbonate (RSC), Permeability Index (PI), Corrosively Ratio (CR), Magnesium Adsorption Ratio (MAR) and Kellies Ratio (KR) were also derived from the primary parameter for IWQI. Both DWQI and IWQI were classified into excellent to unfit condition of groundwater quality based on their Water Quality Index (WQI). Based on their severity of WQI the sub-basin further classified into sustainable to unsustainable state of groundwater quality for sustainable development.

\subsection{Primary physical and chemical parameters}

\subsubsection{Potential hydrogen $(\mathrm{pH})$}

$\mathrm{pH}$ in ground water is an important parameter, because it controls many chemical and biological processes that occur in the water. $\mathrm{pH}$ is measured on a scale that ranges from 0 to 14 , with 7 considered neutral. The ground water with $\mathrm{pH}<7$ are acidic, while values $>7$ are basic. $\mathrm{pH}$ can be used as a proxy of water quality conditions since water $\mathrm{pH}$ is easily changed by chemical pollution. In the study area $\mathrm{pH}$ level of water varies from 7.87 and 8.28 and it is in desirable limit as specified by the WHO.

\subsubsection{Total dissolved solids (TDS)}

The high TDS in ground water may be due to evaporation contribution from irrigation water and rock water interaction. Once again, the average pre and post monsoon ground water samples show the same trend of TDS concentration. The TDS concentration in ground water has been about $61 \%$ of area holding desirable quality of ground water.

\subsubsection{Total hardness (TH)}

Ground water hardness is defined as the content of metallic ions, primarily $\mathrm{Ca}^{+}, \mathrm{Mg}^{+}$that react with sodium soaps to form 'soap curd' or that react with negative ions to form a scaly crust on pipe surfaces. Hardness may not be health related contaminants, however it causes taste problems. Groundwater hardness in Uppar Odai sub-basin indicated that about $87 \%$ of area fall under permissible category, $6 \%$ of area categorized under unsuitable quality and remaining $7 \%$ under desirable quality of water. 
Table 1: Physical and Chemical Parameters of Groundwater Samples in the Upper Odai Show Statistical Summary.

\begin{tabular}{llllll}
\hline Parameters (Unit) & Range & Mean & Mode & Median & SD \\
\hline $\mathrm{pH}(\mathrm{mg} / \mathrm{l})$ & $7.87-8.37$ & 8 & 8 & 8 & 0 \\
$\mathrm{TDS}(\mathrm{mg} / \mathrm{l})$ & $402-7697$ & 1900 & 402 & 892 & 2124 \\
$\mathrm{TH}(\mathrm{mg} / \mathrm{l})$ & $51-775$ & 193 & 62 & 137 & 193 \\
$\mathrm{Ca}(\mathrm{mg} / \mathrm{l})$ & $16-860$ & 146 & 24 & 95 & 191 \\
$\mathrm{Mg}(\mathrm{mg} / \mathrm{l})$ & $19-194$ & 58 & 38 & 46 & 40 \\
$\mathrm{Na}(\mathrm{mg} / \mathrm{l})$ & $30-544$ & 153 & 42 & 120 & 124 \\
$\mathrm{~K}(\mathrm{mg} / \mathrm{l})$ & $4-97$ & 26 & 8 & 14 & 26 \\
$\mathrm{HCO}_{3}(\mathrm{mg} / \mathrm{l})$ & $59-321$ & 179 & 256 & 174 & 64 \\
$\mathrm{CO}_{3}(\mathrm{mg} / \mathrm{l})$ & $0.18-2.72$ & 0 & 0 & 0 & 1 \\
$\mathrm{Cl}_{(\mathrm{mg} / \mathrm{l})}$ & $29-567$ & 185 & 87 & 158 & 122 \\
$\mathrm{SO}_{4}(\mathrm{mg} / \mathrm{l})$ & $49-968$ & 244 & 115 & 165 & 226 \\
$\mathrm{NO}_{3}(\mathrm{mg} / \mathrm{l})$ & $57-223$ & 122 & 57 & 106 & 49 \\
$\mathrm{~F}(\mathrm{mg} / \mathrm{l})$ & $0.14-1.19$ & 1 & 1 & 1 & 0 \\
\hline
\end{tabular}

\subsubsection{Calcium (Ca)}

Calcium is an essential plant nutrient found in the soil and it ranges between 24 to $860 \mathrm{ppm}$ in ground water in the study area. Calcium occurs as calcium carbonate in limestone, which is the major source for calcium in ground water. Calcium helps to keep soil in good physical condition, which favors good water penetration and easy tilling. The drinking water quality is concerned about $22 \%$ of the area holding desirable quality of water; majority of the area (about $66 \%$ ) with permissible limit of $\mathrm{Ca}$ concentration and about $12 \%$ of sub-basin the quality of water in terms of 'ca' exceeds the permissible limit.

\subsubsection{Magnesium (Mg)}

Chemical reactions of magnesium in the ground water are similar to those of calcium. The $\mathrm{Mg}$ concentrations in ground water vary from 19 to $512 \mathrm{mg} / \mathrm{l}$ in the sub-basin. Magnesium normally occurs at about half the concentration of calcium; however, in the study area irrigation water contributes almost equal concentration of ' $\mathrm{Ca}$ '. At few locations, irrigation water contributes high concentration of $\mathrm{Mg}$ which is higher than $\mathrm{Ca}$. As per WHO norms, nearly $30 \%$ of the Uppar Odai sub-basin, the 'Mg' concentration exceeds permissible limit of drinking water quality. The desirable quality is restricted to very limited zone.

\subsubsection{Sodium and potassium}

Sodium is one of the dominant cations in ground water, with a concentration ranging from 30 to $1224 \mathrm{mg} / \mathrm{l}$ and Potassium concentration in ground water ranges from 4 to $98 \mathrm{mg} / \mathrm{l}$ in the Uppar Odai sub-basin. The high sodium water may produce harmful levels of exchangeable sodium in most of the soil. The sodium concentrations in pre and post monsoon ground water samples show almost same level. The increasing sodium content in ground water is likely due to leaching of soaps and agriculture area due to the use of fertilizer. About 56\% sodium exceeds allowable limit as per WHO standard. In the case of potassium concentration, most of the ground water samples come under permissible limit. The source of potassium is likely due to silicate minerals such as orthoclase, microcline, hornblende, muscovite and biotite in igneous and metamorphic rocks. The evaporate deposits like gypsum and sulphate release considerable amount of potassium into ground water. The main reason for increased of potassium into ground water due to agricultural activities. The recent trend of potassium concentration in groundwater about $87 \%$ exceeds allowable limit of WHO standards for domestic purposes.

\subsubsection{Carbonate and bicarbonate ( $\mathrm{CO3}$ and $\mathrm{HCO3})$}

The carbon dioxide dissolved by naturally circulating water appears in chemical analysis as bicarbonate and carbonate ions. The concentration of carbonates in natural water is a function of dissolved carbon dioxide, temperature, $\mathrm{pH}$, cations and other dissolved salts. Concentrations of bicarbonate and carbonate vary in ground water between 59 to $321 \mathrm{mg} / \mathrm{l}$ and 0 to $2.72 \mathrm{mg} / \mathrm{l} \mathrm{respec}$ tively. This is far below the expected range of $120 \mathrm{mg} / \mathrm{l}$ stipulated by WHO. It is noteworthy that carbonates and bicarbonates ions produce alkalinity. Alkalinity is therefore a reliable measure of carbonate and bicarbonate for most natural water. Temporary hardness caused by presence of these ions in water for containing large amounts of bicarbonate and alkalinity is undesirable to many industries.

\subsubsection{Chloride (Cl)}

The concentration of chloride in ground water ranges between 29 to $3326 \mathrm{mg} / \mathrm{l}$ in the study area. Chlorinated pesticides and solvents may be the main cause for such high concentration. Also leaching of chlorine from acid igneous rocks cause variation of the $\mathrm{Cl}^{-}$concentration. Chloride ion has a direct toxic effect on some plants and also contributing to the salinity of the soil. The untreated effluents discharged into the river course and ponds and the leachate join the ground water table. Chloride concentrations in excess of $250 \mathrm{mg} / \mathrm{l}$ can give rise to detectable taste in water. Chloride originates from sodium chloride which gets dissolved in water from rocks and soil. It is a good indicator of ground water quality and its concentration in ground water will increase if it is mixed with sewage or sea water. The ground water data have shown that about $58 \%$ of sub-basin area covered by permissible chloride concentration, $24 \%$ of area is under desirable limit and $18 \%$ of area is having chloride concentration in undesirable condition.

\subsubsection{Sulphate $\left(\mathrm{SO}_{4}\right)$}

The sulphate ion causes no particular harmful effects to soil or plants; however, it contributes increase of salinity in the soil solution. Sulphate is the next predominant anion, with a concentration varying between 49 to $1827 \mathrm{mg} / 1$ in ground water of Uppar Odai sub-basin. Sulphate reacts with human organs if the value exceeds the maximum allowable limit of $400 \mathrm{mg} / 1$ and causes a laxative effect on human system with the excess magnesium in ground water. In the present context, sulphate concentration in ground water shows about $50 \%$ of the area exceeds the permissible limit and only $17 \%$ of area fall in desirable category and remaining $33 \%$ under permissible zone.

\subsubsection{Nitrate $\left(\mathrm{NO}_{3}\right)$}

The sources of nitrate in ground water are fertilizers, human and animal waste, non-anthropogenic sources like fixation, rock weathering and atmospheric deposition. The concentration of nitrogen in ground water is derived from the biosphere (Saleh et al, 1999). The high nitrate concentration is due to the intensive urbanization and industrialization. Under aerobic conditions nitrogen is finally converted into nitrate by nitrifying bacteria (Tindall et al, 1995). Nitrate becomes toxic when it is reduced to nitrite, a process that can occur in the stomach. These cause Blue Baby Syndrome Methemo globinemia. The desirable limit of nitrate in ground water is $45 \mathrm{mg} / \mathrm{l}$. In the study area $\mathrm{NO}_{3}$ concentration varies from 56pm to $222 \mathrm{ppm}$ which indicates all the samples fall above maximum allowable limit.

\subsubsection{Fluoride (F)}

The fluoride content of ground water varies greatly depending on the geological settings and type of rocks. The fluoride contents of water may increase during evaporation if solution remains in equilibrium with calcite and alkalinity is greater than hardness. Dissolution of evaporative salts deposited in arid zone may be an important source of fluoride (Frencken, 1992). The WHO guideline value for fluoride in drinking water is $1.5 \mathrm{mg} / \mathrm{l}$. Above $1.5 \mathrm{mg} / \mathrm{l}$ mottling of teeth may occur to an objectionable degree. Concentrations between 3 and $6 \mathrm{mg} / \mathrm{l}$ may cause skeletal fluorosis. Continued consumption of water with fluoride levels in excess of 10 $\mathrm{mg} / \mathrm{l}$ can result in crippling fluorosis. In the context, the fluoride concentration in ground water shows that about $97 \%$ of the area is under permissible limit. 


\subsection{Drinking water quality index (DWQI)}

The 'DWQI' has been calculated to evaluate the suitability of groundwater quality of the Uppar Odai sub-basin for drinking purposes. The WHO (2004) standards for drinking purposes have been considered for the calculation of DWQI. The physical and chemical parameters of $\mathrm{pH}$, TDS, TH, $\mathrm{Ca}, \mathrm{Mg}, \mathrm{Na}, \mathrm{K}, \mathrm{HCO}_{3}, \mathrm{CO}_{3}$ $\mathrm{Cl}, \mathrm{SO}_{4}, \mathrm{NO}_{3}$ and $\mathrm{F}$ were utilized. Each of 13 parameters has been assigned a weight $\left(\mathrm{w}_{\mathrm{i}}\right)$ according to its relative importance in the overall quality of water for drinking purposes (Table 2). The maximum weight of 5 has been assigned to parameters such as nitrate due to their major importance in water quality assessment. Other parameters like calcium, magnesium, sodium and potassium were assigned a weight between 1 and 5 depending on their importance in the overall quality of water for drinking purposes. The relative weight $\left(\mathrm{W}_{\mathrm{i}}\right)$ is computed using a weighted arithmetic index method given below (Brown et al., 1972; Horton, 1965; Tiwari and Manzoor, 1988) in the following steps.

$\mathrm{W}_{\mathrm{i}}=\frac{\mathrm{W}_{\mathrm{i}}}{\sum_{\mathrm{i}=1}^{\mathrm{n}} \mathrm{w}_{\mathrm{i}}}$

A quality rating scale (Qi) for each parameter is assigned by dividing its concentration in each water sample by its respective standard according to the guidelines of WHO (2004) and then multiplied by 100 .

$\mathrm{Q}_{\mathrm{i}}=\frac{\mathrm{C}_{\mathrm{i}}}{\mathrm{s}_{\mathrm{i}}} \times 100$

Where Qi is the quality rating, $\mathrm{Ci}$ is the concentration of each chemical parameter in each water sample in $\mathrm{mg} / \mathrm{l}$, and $\mathrm{Si}$ is the WHO drinking water standard for each chemical parameter in $\mathrm{mg} / \mathrm{l}$ according to the guidelines of WHO (2004).

The $\mathrm{SI}_{\mathrm{i}}$ is first determined for each chemical parameter, which is then used to determine the WQI as per the following equation:

$\mathrm{SI}_{\mathrm{i}}=\mathrm{Wi} \times \mathrm{Qi}$

Where $\mathrm{SI}_{\mathrm{i}}$ is the sub index of $\mathrm{i}^{\text {th }}$ parameter and Qi is the rating based on concentration of $i^{\text {th }}$ parameter. The overall drinking water quality index (WQI) was calculated by adding together each sub index values of each groundwater samples (Table 3) as follows:

$\mathrm{WQI}=\Sigma \mathrm{SI}_{\mathrm{i}}$

Table 2: WHO standards weight $\left(\mathrm{w}_{\mathrm{i}}\right)$ and calculated relative weight $\left(\mathrm{W}_{\mathrm{i}}\right)$ for each parameter

\begin{tabular}{llll}
\hline Parameters & WHO standard & Weight $\left(\mathrm{w}_{\mathrm{i}}\right)$ & Relative weight $\left(\mathrm{W}_{\mathrm{i}}\right)$ \\
\hline $\mathrm{pH}(\mathrm{mg} / \mathrm{l})$ & $7-9.2$ & 4 & 0.105 \\
$\mathrm{TDS}(\mathrm{mg} / \mathrm{l})$ & $500-1500$ & 4 & 0.105 \\
$\mathrm{TH}(\mathrm{mg} / \mathrm{l})$ & $100-500$ & 2 & 0.053 \\
$\mathrm{Ca}(\mathrm{mg} / \mathrm{l})$ & $75-200$ & 2 & 0.053 \\
$\mathrm{Mg}(\mathrm{mg} / \mathrm{l})$ & $30-150$ & 2 & 0.053 \\
$\mathrm{Na}(\mathrm{mg} / \mathrm{l})$ & $50-200$ & 2 & 0.053 \\
$\mathrm{~K}(\mathrm{mg} / \mathrm{l})$ & $10-12$ & 2 & 0.053 \\
$\mathrm{HCO}(\mathrm{mg} / \mathrm{l})$ & $300-600$ & 4 & 0.105 \\
$\left.\mathrm{Cl}_{3} \mathrm{mg} / \mathrm{l}\right)$ & $250-600$ & 3 & 0.079 \\
$\mathrm{SO}_{4}(\mathrm{mg} / \mathrm{l})$ & $200-600$ & 4 & 0.105 \\
$\mathrm{NO}_{3}(\mathrm{mg} / \mathrm{l})$ & $50-100$ & 5 & 0.132 \\
$\mathrm{~F}(\mathrm{mg} / \mathrm{l})$ & $0-1.5$ & 4 & 0.105 \\
$\mathrm{Total}$ & & 38 & 1.000 \\
\hline
\end{tabular}

\subsection{Irrigation water quality indices (IWQI)}

The various irrigation water quality indices were derived from the primary parameter of drinking water quality (Table 4).

\subsubsection{Sodium adsorption ratio (SAR)}

SAR is an important parameter for determining the suitability of ground water for irrigation because it is a measure of alkali/sodium hazard to crops. SAR is calculated using the following formula where the concentration of all ions is in meq/l;

$\mathrm{SAR}=\frac{\mathrm{Na}^{+}}{\sqrt{\frac{\mathrm{Ca}^{2+}+\mathrm{Mg}^{2+}}{2}}}$

Table 3: Water Classification of Each Groundwater Sample for Quality Rating (Qi), Sub Index (Sii) and WQI

\begin{tabular}{|c|c|c|c|c|c|c|c|c|c|c|c|c|c|c|c|c|c|c|c|c|c|c|c|c|c|}
\hline 包 & & C & & & & & & & & & & & & & & & & $\frac{2}{1}$ & & & & & & & $\underset{0}{ٍ}$ \\
\hline & . & $\cong$ & ?. & $\cong$ & ᄋ. & $\cong$ & 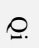 & $\cong$ & o. & $\cong$. & ○. & $\cong$ & o. & $\cong$ & o. & $\cong$ & ᄋ. & $\cong$ & ᄋ & $\cong$ & $\rho$ & $\cong$ & ᄋ. & $\cong$ & \\
\hline- & $\stackrel{゚}{\stackrel{+}{+}}$ & $\stackrel{0}{\circ}$ & $\underset{j}{a}$ & $\begin{array}{l}\infty \\
\infty\end{array}$ & $\stackrel{\infty}{\stackrel{\infty}{N}}$ & $\stackrel{t}{i}$ & $\begin{array}{l}\vec{N} \\
\text { o }\end{array}$ & $\infty$ & $\stackrel{9}{ \pm}$ & $\stackrel{\omega}{+}$ & $\begin{array}{l}\stackrel{N}{\infty} \\
0\end{array}$ & $\vec{\sigma}$ & $\stackrel{0}{\longleftarrow}$ & $\vec{b}$ & : & $\overrightarrow{i n}$ & 竞 & in & $\vec{\omega}$ & $\vec{\nabla}$ & $\underset{I}{\stackrel{I}{I}}$ & $\ddot{\sigma}$ & iे & $\stackrel{\infty}{\omega}$ & $\begin{array}{l}\bar{c} \\
u a\end{array}$ \\
\hline N & 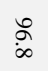 & $\vec{i}$ & $\stackrel{\tilde{N}}{\tilde{\omega}}$ & $\ddot{u}$ & $\vec{\omega}$ & $\stackrel{0}{y}$ & $\stackrel{N}{0}$ & 으 & $\stackrel{\infty}{*}$ & $\overline{i r}$ & $\stackrel{0}{\circ}$ & $\underset{\infty}{+\infty}$ & बे & w & $\underset{\infty}{\omega}$ & $\underset{i}{w}$ & $\underset{\omega}{N}$ & $\stackrel{N}{0}$ & $\underset{\infty}{\sim}$ & $\underset{i}{\omega}$ & $\stackrel{\infty}{\infty}$ & $\Xi$ & $\underset{d}{\stackrel{d}{v}}$ & $\overrightarrow{6}$ & 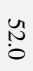 \\
\hline$\omega$ & 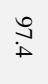 & $\vec{i}$ & $\stackrel{\sim}{N}$ & $\stackrel{\omega}{+}$ & $\bar{u}$ & $\stackrel{\infty}{\circ}$ & : & $\Xi$ & 岕 & $\bar{\omega}$ & 岕 & $\Xi$ & प̆ & $\stackrel{n}{v}$ & $\underset{N}{\sim}$ & $\stackrel{\omega}{+}$ & in & 8 & $\ddot{v}$ & $\Xi$ & 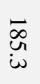 & $\begin{array}{l}\tilde{N} \\
\dot{i n}\end{array}$ & $\stackrel{\text { un }}{2}$ & $\dot{o}$ & $\stackrel{u}{I}$ \\
\hline A & $\begin{array}{l}0 \\
a \\
a\end{array}$ & $\vec{i}$ & $\frac{\infty}{\dot{\sigma}}$ & $\overrightarrow{6}$ & $\begin{array}{l}\text { b } \\
\omega\end{array}$ & $\ddot{o}$ & $\stackrel{\vec{\omega}}{\overrightarrow{0}}$ & $\dot{\omega}$ & 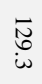 & $\hat{b}$ & $\stackrel{\vec{\sigma}}{\circ}$ & 冓 & ğ & $\stackrel{\omega}{\mathscr{O}}$ & $\underset{\sim}{N}$ & $\tilde{\omega}$ & $\stackrel{\sim}{\stackrel{v}{v}}$ & $\dot{a}$ & $\stackrel{\infty}{0}$ & $\stackrel{\infty}{+}$ & ŭ & $\tilde{u}^{\prime}$ & $\stackrel{t}{+}$ & $\vec{\sigma}$ & $\underset{\infty}{\underset{\infty}{7}}$ \\
\hline$u$ & $\stackrel{2}{3}$ & $\vec{i}$ & $\underset{\infty}{\vec{\sigma}}$ & $\stackrel{\infty}{\forall}$ & $\underset{\substack{\infty \\
i \sim}}{ }$ & $\stackrel{n}{\alpha}$ & $\stackrel{\sim}{\tilde{\sigma}}$ & $\underset{\infty}{N}$ & $\stackrel{0}{i}$ & $\underset{\infty}{+\infty}$ & $\stackrel{N}{N}$ & $\stackrel{F}{\vec{D}}$ & $\stackrel{0}{*}$ & $\overrightarrow{6}$ & $\underset{\infty}{N}$ & $\stackrel{N}{a}$ & $\stackrel{N}{\sigma}$ & $\stackrel{n}{\sim}$ & N & $\stackrel{N}{\sim}$ & $\begin{array}{l}\vec{\infty} \\
\stackrel{\infty}{+}\end{array}$ & $\underset{+}{+}$ & $\vec{u}$ & $\vec{a}$ & $\stackrel{?}{0}$ \\
\hline$a$ & 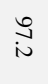 & $\vec{i}$ & $\stackrel{ \pm}{*}$ & $\ddot{o}$ & $\overline{\text { i }}$ & $\stackrel{\circ}{\circ}$ & बू & $\stackrel{\circ}{\infty}$ & ă & $\stackrel{\circ}{\infty}$ & ज. & 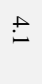 & $\underset{v}{ \pm}$ & $\ddot{i n}$ & $\stackrel{\omega}{\omega}$ & $\underset{\infty}{\omega}$ & 咅 & 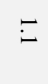 & $\underset{\text { i }}{\stackrel{w}{*}}$ & $\stackrel{w}{\sim}$ & 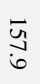 & $\underset{\infty}{\tilde{O}}$ & $\stackrel{\omega}{0}$ & $\underset{\infty}{\omega}$ & $\underset{\infty}{\stackrel{\rho}{\infty}}$ \\
\hline$\checkmark$ & 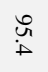 & ర్ & $\underset{\infty}{N}$ & $\stackrel{N}{N}$ & $\stackrel{N}{+}$ & $\stackrel{-}{*}$ & N̦ & \& & $\stackrel{\sim}{\text { w }}$ & $\bar{\omega}$ & $\stackrel{N}{\circ}$ & 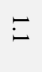 & प̆ & $\stackrel{N}{\sim}$ & $\begin{array}{l}\underset{\omega}{\omega} \\
i\end{array}$ & $\tilde{w}_{i}$ & $\hat{\omega}$ & in & $\stackrel{\infty}{i}$ & 8 & $\overline{\vec{w}}$ & $\stackrel{N}{a}$ & : & iे & $\stackrel{\sim}{N}$ \\
\hline$\infty$ & $\begin{array}{l}\infty \\
\text { in }\end{array}$ & $\vec{\omega}$ & 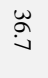 & 虫 & $\bar{u}$ & $\stackrel{\infty}{\infty}_{0}$ & $\underset{\infty}{\infty}$ & $\bar{u}$ & $\stackrel{n}{v}$ & $\stackrel{\sim}{\sim}$ & 竞 & ב & बे & $\tilde{i n}^{\prime}$ & : & $\ddot{\omega}$ & $\begin{array}{l}\vec{\infty} \\
\infty\end{array}$ & in & $\underset{\infty}{N}$ & $\bar{\omega}$ & $\vec{w}$ & $\vec{\omega}$ & $\begin{array}{l}\omega \\
\infty \\
0\end{array}$ & $\dot{0}$ & t \\
\hline 0 & ¿े & $\ddot{\circ}$ & 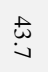 & $\vec{a}$ & $\underset{N}{N}$ & ஜू & $\bar{o}$ & $\stackrel{\infty}{\infty}$ & $\underbrace{\vec{b}}_{\omega}$ & $\overline{0}$ & ir & $\stackrel{\omega}{v}$ & बू & $\begin{array}{l}\infty \\
\infty \\
\infty\end{array}$ & 岂 & $\ddot{a}$ & $\begin{array}{l}\vec{\sigma} \\
\text { in }\end{array}$ & in & $\underset{\infty}{\vec{\infty}}$ & $\overrightarrow{6}$ & స్ర్ర & $\vec{\nabla}$ & 㟧 & $\ddot{\infty}$ & $\begin{array}{l}\text { th } \\
\text { ¿ }\end{array}$ \\
\hline
\end{tabular}




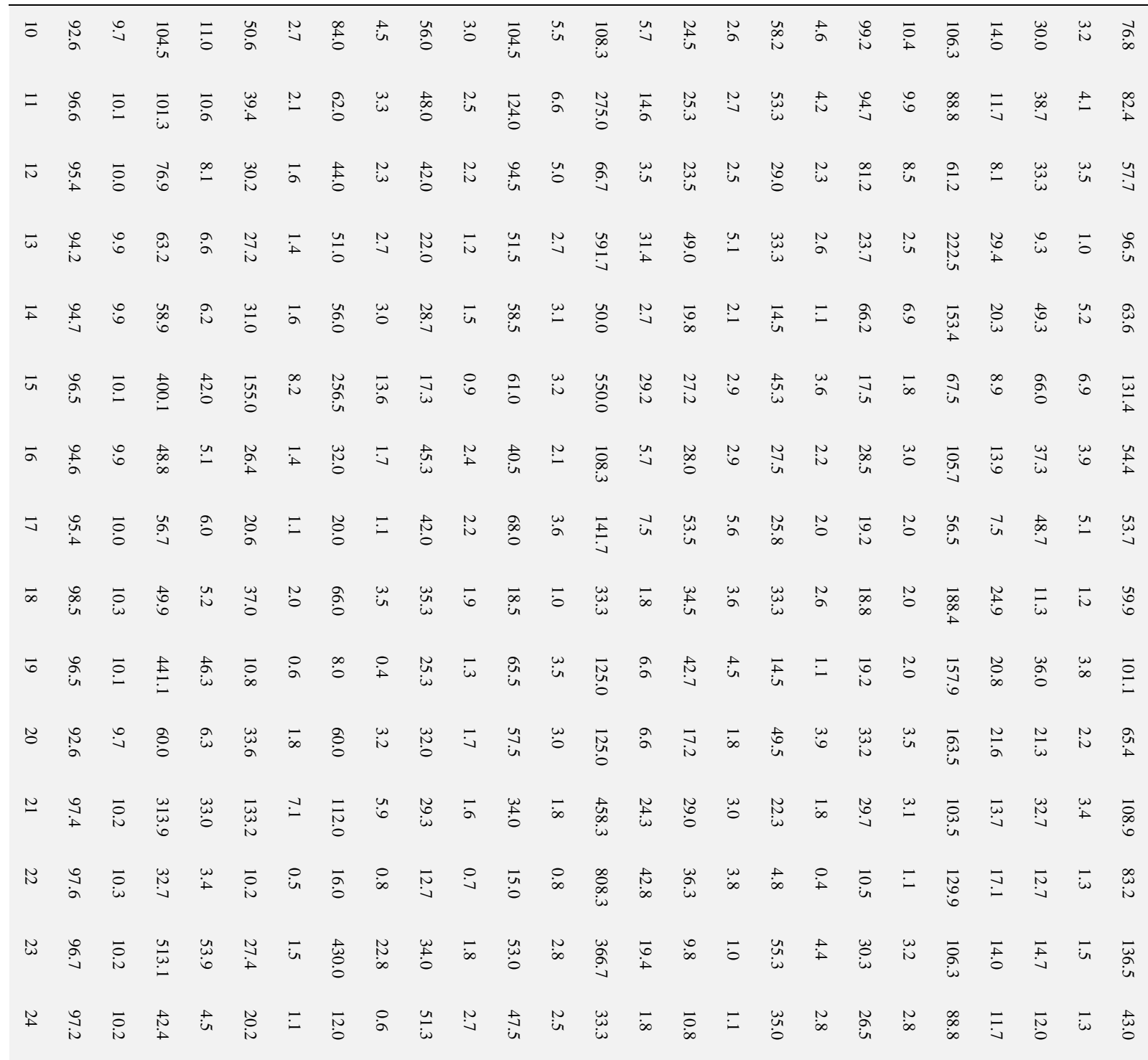

Table 4: Water quality classification based on WQI value

\begin{tabular}{lllllllll}
\multicolumn{7}{c}{ Table 4: Water quality classification based on WQI value } \\
\hline Sample & SAR & SSP & RSC & PI & CR & MAR & KR & IWQI \\
\hline 1 & 30.8 & 52.7 & 0.6 & 54.0 & 7.1 & 24.2 & 1.1 & 171 \\
2 & 31.4 & 73.9 & 2.8 & 78.6 & 2.2 & 64.2 & 2.7 & 256 \\
3 & 10.4 & 47.7 & 2.5 & 55.2 & 0.8 & 48.7 & 0.8 & 166 \\
4 & 21.8 & 46.2 & 0.3 & 43.1 & 5.0 & 41.5 & 0.7 & 159 \\
5 & 49.6 & 69.7 & 0.6 & 70.8 & 2.8 & 56.8 & 2.3 & 253 \\
6 & 29.1 & 75.3 & 3.9 & 80.4 & 1.4 & 42.9 & 2.8 & 236 \\
7 & 7.5 & 43.6 & 3.2 & 54.0 & 0.5 & 61.3 & 0.7 & 171 \\
8 & 16.5 & 59.2 & 2.3 & 64.9 & 1.4 & 25.3 & 1.3 & 171 \\
9 & 25.5 & 72.5 & 3.4 & 76.9 & 1.3 & 47.5 & 2.3 & 230 \\
10 & 18.6 & 46.8 & 0.6 & 48.0 & 7.6 & 33.3 & 0.8 & 156 \\
11 & 25.1 & 58.9 & 0.8 & 58.6 & 6.8 & 36.7 & 1.3 & 188 \\
12 & 21.8 & 56.6 & 0.9 & 59.1 & 5.3 & 41.7 & 1.3 & 187 \\
13 & 12.5 & 56.3 & 2.2 & 50.5 & 1.5 & 24.4 & 0.8 & 148 \\
14 & 13.3 & 44.2 & 0.8 & 47.0 & 4.5 & 27.7 & 0.8 & 138 \\
15 & 7.4 & 25.9 & 0.3 & 20.4 & 3.0 & 4.8 & 0.2 & 62 \\
16 & 10.0 & 41.6 & 1.3 & 44.1 & 2.4 & 51.5 & 0.6 & 152 \\
17 & 19.0 & 59.8 & 3.1 & 64.4 & 1.1 & 61.2 & 1.3 & 210 \\
18 & 3.8 & 18.1 & 1.1 & 23.1 & 1.9 & 28.6 & 0.2 & 77 \\
19 & 25.2 & 73.0 & 4.8 & 79.5 & 0.9 & 70.4 & 2.4 & 256 \\
20 & 12.5 & 43.6 & 0.6 & 44.2 & 6.1 & 28.6 & 0.7 & 136 \\
21 & 5.9 & 31.5 & 0.6 & 24.2 & 2.2 & 16.4 & 0.3 & 81 \\
22 & 5.9 & 71.3 & 4.3 & 55.3 & 0.5 & 37.3 & 0.6 & 175 \\
23 & 5.0 & 14.1 & 0.1 & 11.2 & 11.1 & 5.6 & 0.1 & 47 \\
24 & 13.4 & 49.5 & 0.6 & 52.6 & 7.1 & 76.2 & 0.9 & 200 \\
\hline & & & & & & & &
\end{tabular}

\subsubsection{Sodium adsorption ratio (SAR)}

SAR is an important parameter for determining the suitability of ground water for irrigation because it is a measure of alka- li/sodium hazard to crops. SAR is calculated using the following formula where the concentration of all ions is in meq/l;

$\mathrm{SAR}=\frac{\mathrm{Na}^{+}}{\sqrt{\frac{\mathrm{Ca}^{2+}+\mathrm{Mg}^{2+}}{2}}}$

The calculated value of SAR in the study area has been shown about $61 \%$ of area under medium suitable. The $32 \%$ of study areas fall under high to very high SAR for irrigation. When SAR values are greater than 9, irrigation water will cause permeability problems on shrinking and swelling in clay soil (Saleh et al. 1999). The higher the SAR values in the water, the greater the risk of $\mathrm{Na}$ which leads to the development of an alkaline soil (Todd 1980), while a high salt concentration in water leads to formation of saline soil. The average Sodium Absorption Ratio (SAR) of ground water in the study area is 18 . In ground water sodium absorption ratio becomes $>18-26 \mathrm{ppm}$, it is called exchangeable sodium percentage.

\subsubsection{Soluble sodium percentage (SSP)}

Wilcox (1955) has proposed classification scheme for rating irrigation water on the basis of soluble sodium percentage (SSP). The SSP was calculated by using following formula:

$\mathrm{SSP}=\frac{\mathrm{Na} \times 100}{\mathrm{Ca}+\mathrm{Mg}+\mathrm{Na}}$

Where, the concentrations of ions are expressed in meq/l. The values of SSP less than 50 indicate good quality of water and higher values (i.e. > 50) show that the water is unsafe for irrigation (USDA, 1954). It is observed from Table 4 that, majority of 
the groundwater samples have SSP values greater than 50, which can be graded as unsuitable for irrigation.

\subsubsection{Residual sodium carbonate (RSC)}

Water containing carbonate plus bicarbonate concentration greater than the calcium plus magnesium concentration, referred as "residual sodium carbonate" and calculated as (Ragunath 1987);

$\mathrm{RSC}=\left(\mathrm{CO}_{3}+\mathrm{HCO}_{3}\right)-(\mathrm{Ca}+\mathrm{Mg})$

Where, all the concentrations are expressed in meq/l. The potential for a sodium hazard is increased as RSC increases, and much of the calcium and sometimes the magnesium are precipitated out of solution when water is applied to the soil. The sodium percentage increases when calcium and magnesium are removed from the solution, increasing the rate of sodium adsorption on soil particles. The presence of RSC in ground water is classified into various categories. In the study area, RSC varies between $1 \mathrm{ppm}$ to 5.77 ppm. Hazards from RSC are low to medium and only at two locations RSC are in the high hazard category.

\subsubsection{Permeability index (PI)}

The permeability index is calculated by the following formula:

$\mathrm{PI}=\frac{\mathrm{Na}+\sqrt{\mathrm{HCO}_{3}}}{(\mathrm{Ca}+\mathrm{Mg}+\mathrm{Na})} \times 100$

Where, all the values are in meq/l. The PI values $>75$ indicate excellent quality of water for irrigation. If the PI values fall in between 25 and 75, they indicate good quality of water for irrigation. However, if the PI values are $<25$, they reflect unsuitable nature of water for irrigation. On the basis of PI, the groundwater in the study area can be classified as good (87\%) for agricultural use.

\subsubsection{Corrosively ratio index (CRI)}

The magnitude of the corrosiveness of water can be assessed by using a perimeter known as Corrositivity ratio Index (CRI), which can be determined by using the following formula.

$\mathrm{CR}=\frac{\frac{\mathrm{Cl}}{35.5+2 \mathrm{SO}_{4}}}{2\left(\mathrm{CO}_{3}+\frac{\mathrm{HCO}_{3}}{100}\right)}$

The water having the Corrositivity ratio less than 1 is safe and non-corrosive. Corrositivity ratio greater than 2 is suggestive of corrosiveness. Most of the groundwater sample in the study area falls in the CR zone less than 1 and so they are safe, suitable and less corrosive and hence can be used for domestic or industrial purposes. The Corrositivity of the groundwater in the study area ranges between 0.026 and 2.225 .

\subsubsection{Magnesium adsorption ratio (MAR)}

The Magnesium Adsorption Ratio (MAR) was calculated using the following equation (Raghunath 1987):

$\mathrm{MAR}=\frac{\mathrm{Mg}^{2+} \mathrm{x} 100}{\mathrm{Ca}^{2+}+\mathrm{Mg}^{2+}}$

Where, all the ionic constituents are expressed in meq/1

\subsubsection{Kelly's ratio (KR)}

Table 5: Water Quality Classification Based on WQI Value

\begin{tabular}{|c|c|c|c|c|c|c|}
\hline $\begin{array}{l}\text { WQI } \\
\text { value } \\
\text { range }\end{array}$ & Water quality & $\begin{array}{l}\text { No. of } \\
\text { samples } \\
\text { (DWQI) }\end{array}$ & $\%$ & $\begin{array}{l}\text { No. of } \\
\text { samples } \\
\text { (IWQI) }\end{array}$ & $\%$ & $\begin{array}{l}\text { Sustainable } \\
\text { state }\end{array}$ \\
\hline$<50$ & Excellent & 2 & 8 & 1 & 4 & Sustainable \\
\hline $\begin{array}{l}51- \\
100\end{array}$ & Good & 16 & 67 & 3 & 12 & Sustainable \\
\hline $\begin{array}{l}101- \\
200\end{array}$ & Poor & 6 & 25 & 14 & 58 & $\begin{array}{l}\text { Slightly Un- } \\
\text { sustainable }\end{array}$ \\
\hline $\begin{array}{l}201- \\
300\end{array}$ & Very poor & Nil & Nil & 6 & 26 & Unsustainable \\
\hline$>301$ & $\begin{array}{l}\text { Unfit for drink- } \\
\text { ing/irrigation }\end{array}$ & Nil & Nil & Nil & Nil & $\begin{array}{l}\text { Highly Unsus- } \\
\text { tainable }\end{array}$ \\
\hline
\end{tabular}

Kelly's ratio was calculated by using the following expression

$$
\mathrm{KR}=\frac{\mathrm{Na}^{+}}{\mathrm{Ca}^{2+}+\mathrm{Mg}^{2+}}
$$

Where, concentrations are expressed in meq/l. The Kelly's ratio of unity or less than one is indicative of good quality of water for irrigation whereas above one is suggestive of unsuitability for agricultural purpose due to alkali hazards (Karanth, 1987). It is observed from Table 4, the majority of the samples in the study area fall more than one. This suggests that, the samples from study area are unsuitable for irrigation.

\section{Results and discussions}

The calculated DWQI were classified into excellent to unfit condition based on the equation 4 (Table 5). The DWQI for 24 ground water samples ranges from 43 to 136.5. Based on these classifications the spatial distributions of DWQI were generated (Fig.3). The high value of DWQI at these stations has been found to be mainly from the higher values of $\mathrm{pH}$, total dissolved solids, total hardness, calcium, magnesium, nitrate, chloride, fluoride and sulphate in the groundwater. About $8 \%$ (2 samples) of ground water samples are of excellent quality in sample stations like as Senjeripudur and Dhali. The distributions of good and poor drinking water quality index respectively in $67 \%$ and $25 \%$ in Uppar Odai sub-basin. The overall view of the Water Quality Index of the present study had a higher DWQI value $(25 \%)$ indicating the deteriorated water quality.

In order to assess the irrigation water quality in Uppar Odai subbasin an attempt has been made to develop a model on Irrigation Water Quality Index (IWQI). The various irrigation water quality indices such as SAR, SSP, RSC, PI, CR, MAR and KR were considered to assess the ground water quality for irrigation. The indices value summed, then classified into excellent to unfit groundwater quality (Table 5). The output has shown only $16 \%$ of area suitable for irrigation, whereas major parts of the area (84\%) fall under poor to very poor category (Fig.3). The result has shown, the quality deterioration in terms of irrigation, which requires sustainable irrigation practices including optimum utilization of fertilizers and selecting organic farming. Based on the quality deterioration the sub-basin further classified into sustainable to highly unsustainable state of groundwater quality for sustainable development.

Due to drinking and irrigation quality deterioration in the subbasin Gibbs plots chloroalkali indices were analyzed for groundwater evolution. Gibbs (1970) plots, in which TDS versus $\mathrm{Na}^{+} /$ $\left(\mathrm{Na}^{+}+\mathrm{Ca}_{2}^{+}\right)$for cations and TDS versus $\mathrm{Cl}^{-} /\left(\mathrm{Cl}^{-}+\mathrm{HCO}_{3}^{-}\right)$for anion, were plotted to illustrate the groundwater evolution process, and the influence of host rock on groundwater chemistry indicated that the samples by and large occupied the rock dominance to evaporation dominance fields (Fig.4). The rock water interaction and aquifer material played major role in evolution of water chemistry, which was further influenced by the evaporation process. Geological location is one of the most important factors affecting groundwater quality (Beck et al. 1985). The role of aquifer material in the evolution of groundwater chemical composition can be further probed by determining Chloroalkali Indices (CAI) for cations (CAI-1) and anions (CAI-2). It is imperative to understand the modifications in water chemistry during. 


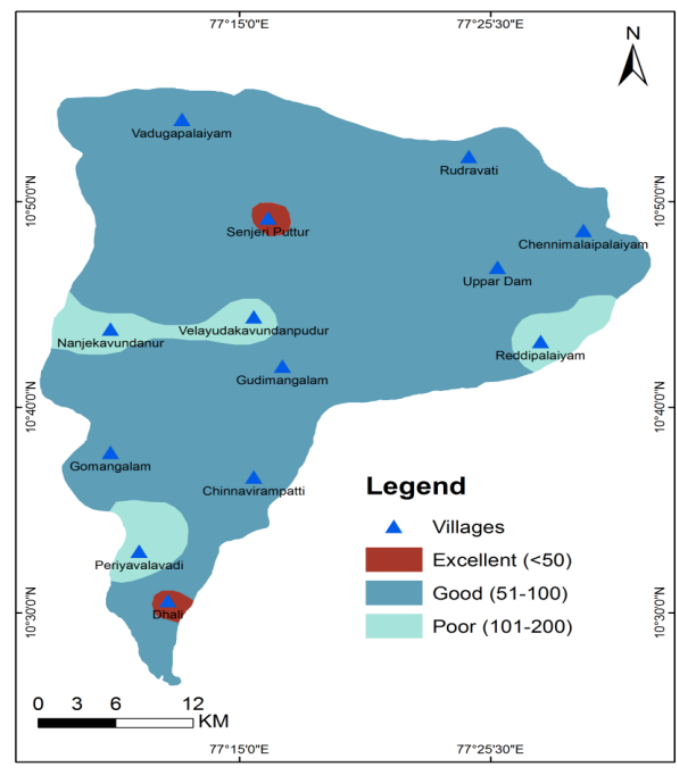

Fig. 2: Spatial Distributions of Quality Concentrations for Drinking

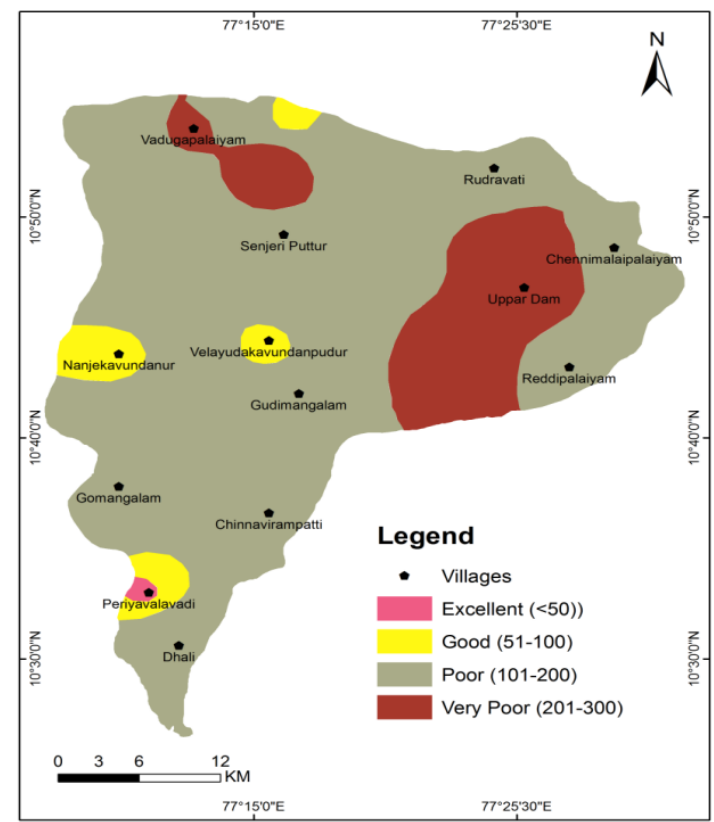

Fig. 3: Spatial Distributions of Quality Concentrations for Irrigation

Its movement and residency time for better evaluation of hydrochemistry of any area more so when different geological formation are involved in a watershed or river basin (Johnson 1979; Sastry 1994). CAI-1 $\left[\mathrm{Cl}^{-}-\left(\mathrm{Na}^{+}+\mathrm{K}^{+}\right)\right] \mathrm{Cl}^{-}$and $\mathrm{CAI}-2\left[\mathrm{Cl}^{-}-\right.$ $\left(\mathrm{Na}^{+}+\mathrm{K}^{+}\right] /\left(\mathrm{SO}_{4}^{2-}+\mathrm{HCO}_{3}^{-}+\mathrm{CO}_{3}^{-}+\mathrm{NO}_{3}^{-}\right)$developed by Schoeller (1967) relates the ion exchange process between groundwater and aquifer material. The CAI-1 and CAI-2 show majority of the samples are negative (Fig.5), it indicates that ion exchange processes are involved between $\mathrm{Na}^{+}-\mathrm{K}^{+}$in water with $\mathrm{Ca}_{2}{ }^{+}-\mathrm{Mg}_{2}{ }^{+}$in host rock, and the exchange is indirect during the evolution of subsurface water chemistry (McIntosh and Walter 2006).
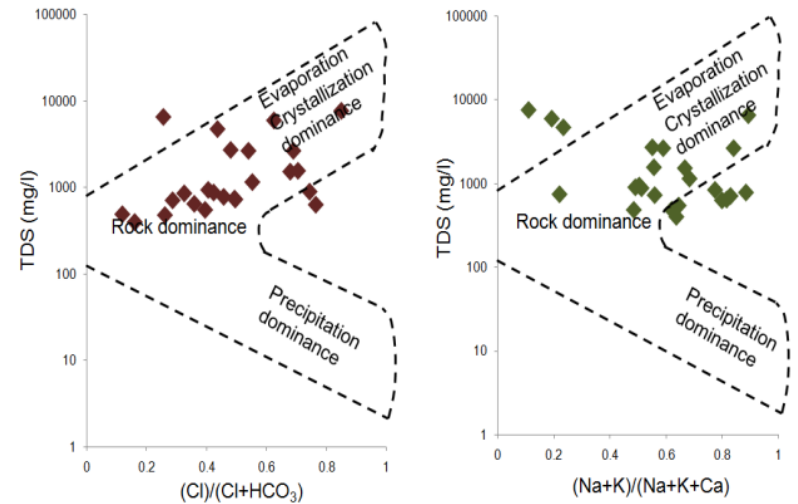

Fig. 4: Graphical Representations Gibbs Diagram
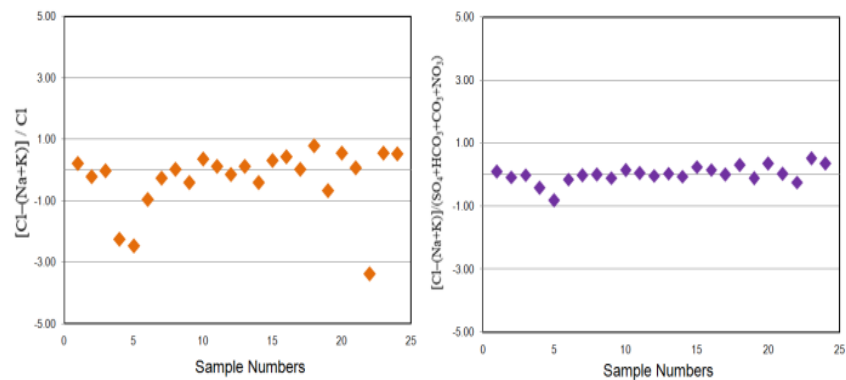

Fig. 5: Graphical Representation of Groundwater Classification

\section{Conclusion}

The present study may help to improve groundwater resource assessment management, achieves social, economic and environmental benefits to support governance and policy. The results have shown that the sub-basin area has undergone significant amount of quality deterioration which requires immediate attention on sustainable ground water management. The spatial distribution maps generated for various physicochemical parameters using GIS techniques could be useful for planners and decision makers for initiating groundwater quality development in the area. The $25 \%$ of DWQI, the groundwater quality may improve due to inflow of freshwater of good quality during monsoon season. About $84 \%$ of the area comes under severely polluted category revealed by the IWQI and demonstrate that groundwater quality in the study area is quite unsatisfactory for irrigation purposes. Apart from ground water assessment, the WQI model can be used for wide ranging of applications. This study can offer the requisite information for the authority to pursue the sustainable approaches on groundwater management and contamination prevention.

\section{Acknowledgement}

The authors thank Water Resource Organization, Chennai, for providing geochemical data. The first author acknowledges UGC for granting RGNF fellowship.

\section{References}

[1] Anbazhagan S, Das MK, GuruBalamurugan (2006) Hydro geochemical studies in hard rock aquifer system, Hosur, India. Indian Journal of Geochemistry Vol 21 December 2006. 22 (2): 519-535.

[2] Anbazhagan S, Archana M.Nair (2004) Geographic Information System and groundwater quality mapping in Panvel basin Maharashtra India. Environmental Geology, International Journal of Geosciences. DOI.10.1007/s00254-003-0932-9. 45:pp.4753-76. http://dx.doi.org/10.1007/s00254-003-0932-9.

[3] Arumugam, K and K. Elangovan, K (2009) Hydrochemical characteristics and groundwater quality assessment in Tirupur Region, Coimbatore District, Tamil Nadu, India, Environ Geol (2009) 58:1509-1520 DOI 10.1007/s00254-008-1652-y. http://dx.doi.org/10.1007/s00254-008-1652-y. 
[4] Bhardwaj, V, and Singh, DS (2010) Surface and groundwater quality characterization of Deoria District, Ganga Plain, India. Environmental Earth Sciences, doi: 10.1007/s12665-010-0709-x. http://dx.doi.org/10.1007/s12665-010-0709-x.

[5] Binoj Kumar, RB and Divya, MP (2012) Spatial Evaluation of Groundwater Quality in Kazhakuttam Block, Thiruvananthapuram District, Kerala. Journal Geological Society of India, Vol.80, pp.48-56. http://dx.doi.org/10.1007/s12594-012-0117-9.

[6] BIS (1991) Indian standard specification for drinking water, Bureau of Indian standards, New Delhi.

[7] Durbude DG, Varadrajan N, Purandara BK (2002) Mapping of groundwater quality parameters in GIS environment. Proceedings of international conference on hydrology and watershed management: with a focal theme on water quality and conservation for sustainable development, Hyderabad, A.P, India, 1, 568-577.

[8] [8] Elango L, Kannan R, SenthilKumar M (2003) Major ion chemistry and identification of hydrogeochemical processes of groundwater in a part of Kancheepuram district, Tamil Nadu. Env Geosci 1(4):157-166

[9] Gagannadha Rao, M. and et al (2007) Spatial variability of Groundwater Chemical Quality in part of Nalgonda district, Andra Pradesh. Jour. Geol. Soc. India, v.69, pp.983-988.

[10] Hakim, MA, Juraimi, AS, Begum, M, Hasanuzzaman, M, Uddin, MK, and Islam, MM (2009) Suitability evaluation of groundwater for irrigation, drinking and industrial purposes, Am. J. Environ. Sci., 5:413-419. http://dx.doi.org/10.3844/ajessp.2009.413.419.

[11] Haris H. Khan, Arina Khan, Shakeel Ahmed and Jerome Perrin (2011) GIS-based impact assessment of land-use changes on groundwater quality: study from a rapidly urbanizing region of South India Environ Earth Sci, 63:1289-1302. DOI 10.1007/s12665-010-0801-2.

[12] Karanth KR (1987) Ground Water Assessment Development and Management (New York: McGraw-Hill), pp.52-89.

[13] Merkel BJ, Friedrich B (2005) Groundwater geochemistry a practical guide to modeling of natural and contaminated aquatic systems. Springer Verlag, Berlin, p.200-206.

[14] Nas B, Berktay A (2008) Groundwater quality mapping in urban groundwater using GIS. Environ Monit Assess 160(1-4): 215-227.

[15] Ramesh, K and Elango, L (2011) Groundwater quality and its suitability for domestic and agricultural use in Tondiar river basin, Tamil Nadu, India. Environ Monit Assess. DOI 10.1007/s10661011-2231-3. http://dx.doi.org/10.1007/s10661-011-2231-3.

[16] Raju J (2007) Hydrogeochemical parameters for assessment of groundwater quality in the upper Gunjanaeru River basin, Cuddapah District, Andhra Pradesh, South India. Environ Geol, 52:1067-1074. http://dx.doi.org/10.1007/s00254-006-0546-0.

[17] Sujatha, D., and Reddy, B. R. (2003). Quality Characterization of groundwater in the south-eastern part of the Ranga Reddy District, Andhra Pradesh, India. Environmental Geology, 44, 579-586. http://dx.doi.org/10.1007/s00254-003-0794-1.

[18] [18] Subramani, T., Elango, L., and Damodarasamy, S. R. (2005). Groundwater quality and its suitability for drinking and agricultural use in Chithar River Basin, Tamil Nadu, India. Environmental Geology, 47, 1099-1110. http://dx.doi.org/10.1007/s00254-005-12430 .

[19] Srinivasa Gowd S (2005) Assessment of groundwater quality for drinking irrigation purposes: a case study of Peddavanka watershed Anantapur District, Andhra Pradesh, India. Environ Geol 48:702712. http://dx.doi.org/10.1007/s00254-005-0009-z.

[20] Singh AK, Mondal GC, Kumar S, Singh TB, Tewary BK, Sinha A (2008) Major ion chemistry, weathering processes and waterquality assessment in upper catchments of Damodar River basin, India Environ Geol 54:745-758. http://dx.doi.org/10.1007/s00254-0070860-1.

[21] Singh Y, Dubey DP, Saxena VK (2002) Assessment of Drinking and industrial utility of groundwater of the Rewa region, central India, Proceedings of international conference on hydrology and watershed management: with a focal theme on water quality and conservation for sustainable development, Hyderabad, A.P., India, 1, 629-637.

[22] Thomas M (2000) the effect of residential development on groundwater quality near Detroit, Michigan. J Amer Water Resour Assoc 36: $\quad$ 1023-1038. http://dx.doi.org/10.1111/j.17521688.2000.tb05707.x

[23] Todd, DK (2001) Groundwater Hydrology. John Wiley and Sons Publication, Canada, pp. 280-281.

[24] Vennila, G, Subramani, T and Elango, L (2008) GIS Based Groundwater Quality Assessment of Vattamalaikarai Basin, Tamil Nadu, India. Nature Environment and Pollution Technology, Vol.7, No.4, pp.585-592.
[25] World Health Organization (2004) Guidelines for drinking-water quality. Third edition. World health organization report, Geneva, 1, Recommendations, pp.102-120. 